\title{
東北大学耳鼻咽喉科における
}

入院患者統計とその推移

志賀 伸之・小林 俊光・高坂 知節

\section{Statistics of Hospitalized Patients in the Department of Otolaryngolgy at Tohoku University Hospital}

\author{
Nobuyuki Shiga, Toshimitsu Kobayashi \\ and Tomonori Takasaka
}

(Tohoku University)

The records of hospitalized patients in the Department of Otolaryngology, Tohoku University School of Medicine during 1978 and 1985 were analyzed, and a comparison was made between the present statistics and those of two earlier periods (1940 1962 and 1972-1978).

The following trends were seen:

1. The number of hospitalized patients per year decreased and the average length of hospitalization increased, mainly because of an increased number of malignant cases requiring longer hospitalization.

2. The incidence of tumors, trauma, foreign bodies, cysts of the paranasal sinuses and nasal bleeding increased, tumors most of all. In contrast, the incidence of inflammatory diseases declined.

3. Recently our department handles not only ear, nose and throat problems, but also those of other areas of the head and neck.

Key words: statistics of hospitalized patients, Tohoku University, Otolaryngology

\section{はじめに}

東北大学医学部附属病院耳鼻咽喉科におりる 入院患者統計は, 過去に A. 昭和 15 年度 36 年度の立木臨床 ${ }^{1)}, \quad$ B. 昭和 47 年度 $~ 52$ 年度の 河本臨床前期2) てついて行なわれている.

今回我々は昭和53年 4 月〜 60年 8 月まで, 7 年 5 か月間の河本臨床後期について，入院患者 統計を行ない,さらに上記二者との比較を行な った.
方 法

データは全て，乙の期間の退院名簿から採取 し，年度別に集計した。

1 人の患者に複数の病名が付いている場合， 原則としてそれぞれ独立の疾患として集計し た、ただし，「腫瘍十頸部転移」という記載の 場合は，頸部転移は独立の疾患ではないと見な

して除外した.

また，同一の患者が数回入退院を繰返してい 
る場合には，同一の病名が付けられている限り は何度入院していても 1 例と見なした.

なお，立木臨床及び河本臨床前期の統計では 頸部転移も独立の疾患として扱い, 再入院む全 て含めている点, 今回とは異なる.

\section{結果及び考按}

この期間の入院患者総数は延べ3186名であ り, 前記の通りこの中から同一疾患による再入 院を除いた延へ2719名を対象とした。

図 1 亿年度每の患者数走示した. 男性は合計 1629名, 女性は1,090名で, 男性が女性のほぼ

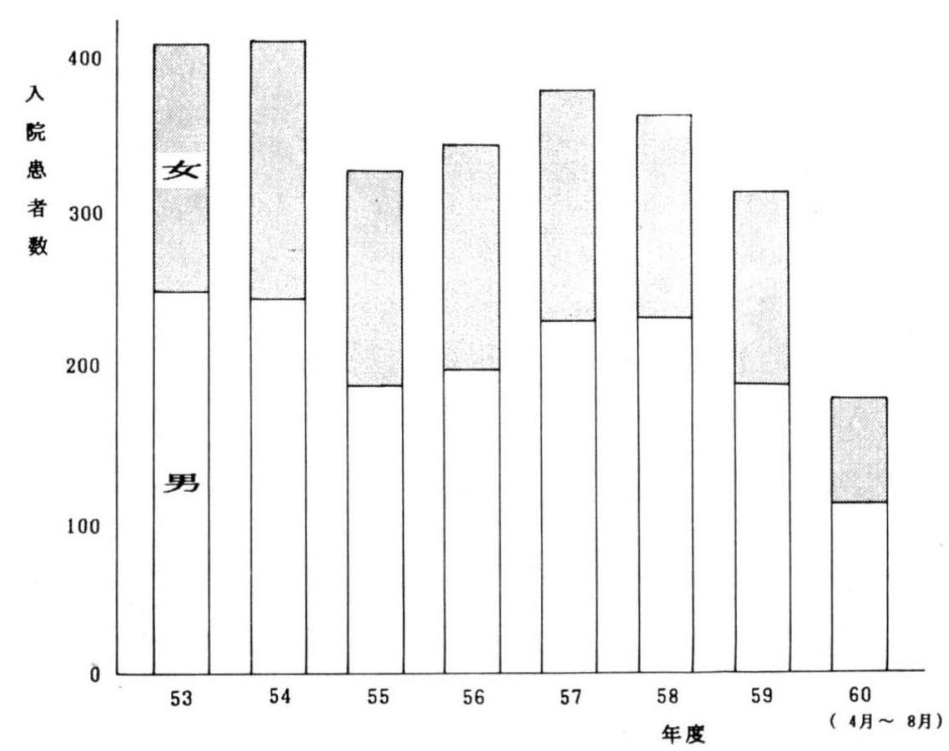

図 I

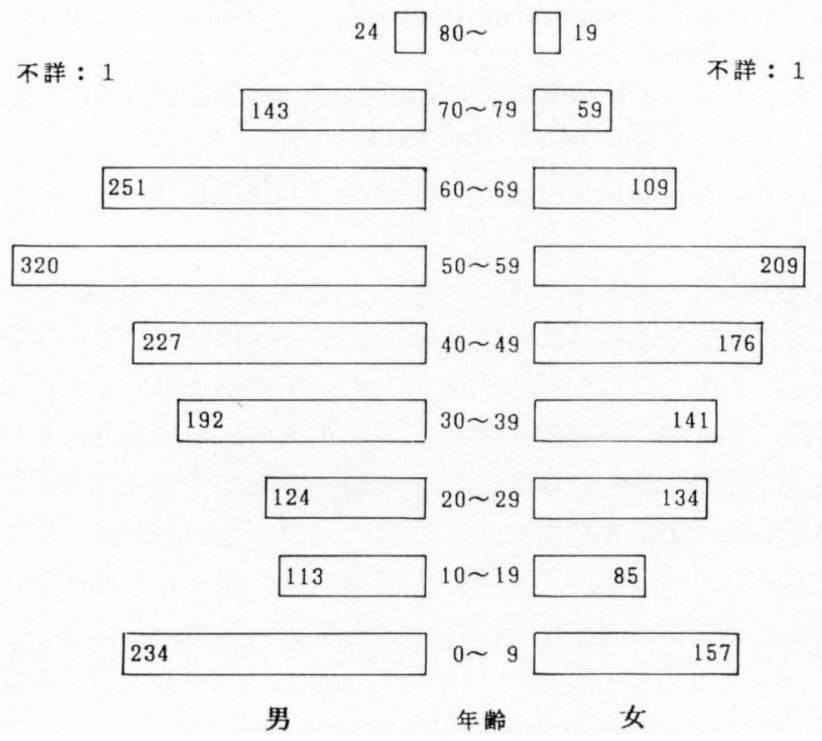

図 2 
1.5 倍となっている. 図 2 に10才ずっ区切って 年龄分布を示す.

全疾患の集計結果を表 1 亿示す. 疾患総数が 2914名と患者数よりも多くなっているのは， 1 人の患者に複数の病名がついている例があるた めである.

次に, この集計結果 (河本臨床後期, 以下 C とする）を，立木臨床（以下A）及び河本臨床 前期（以下B）の集計結果と比較してみた。
図 3 は部位別にみた割合の推移である，鼻・ 副鼻腔疾患は減少している，Aから $\mathrm{B} ， \mathrm{~A}$ から $\mathrm{C} へ$ の堿少は統計学的に有意 $(\mathrm{p}<0.001)$ で ある. 耳矤患の減少 $(\mathrm{p}<0.01)$ も同様に有意 である．喉頭疾患はAから B，AからCへと有 意に増加（ $\mathrm{p}<0.001 ）$ している。咽頭疾患は $\mathrm{A}$ と $\mathrm{B}$ には有意差がないが $\mathrm{B}$ から Cへは有意に

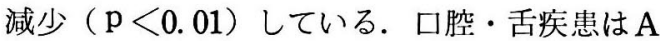
加 B ・ C へ有意に増加 $(\mathrm{p}<0.001 ）$ してい

総疾患数

A.
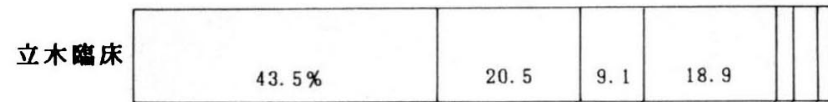

14,905

B. 河本臨床前期
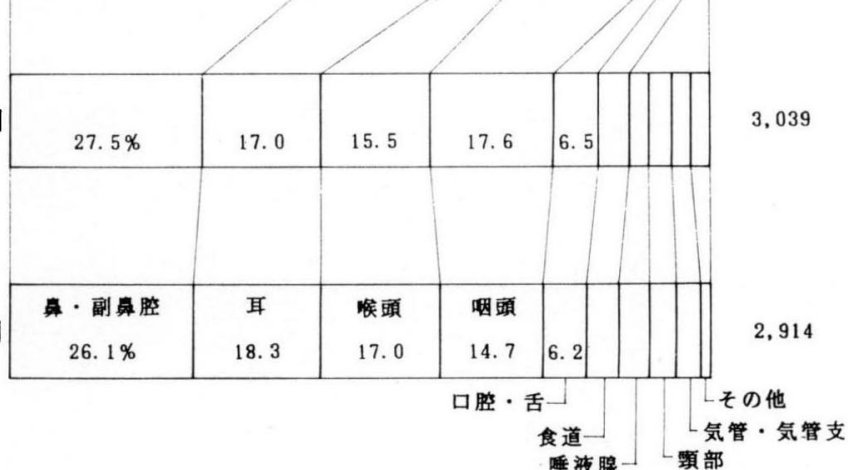

図 3

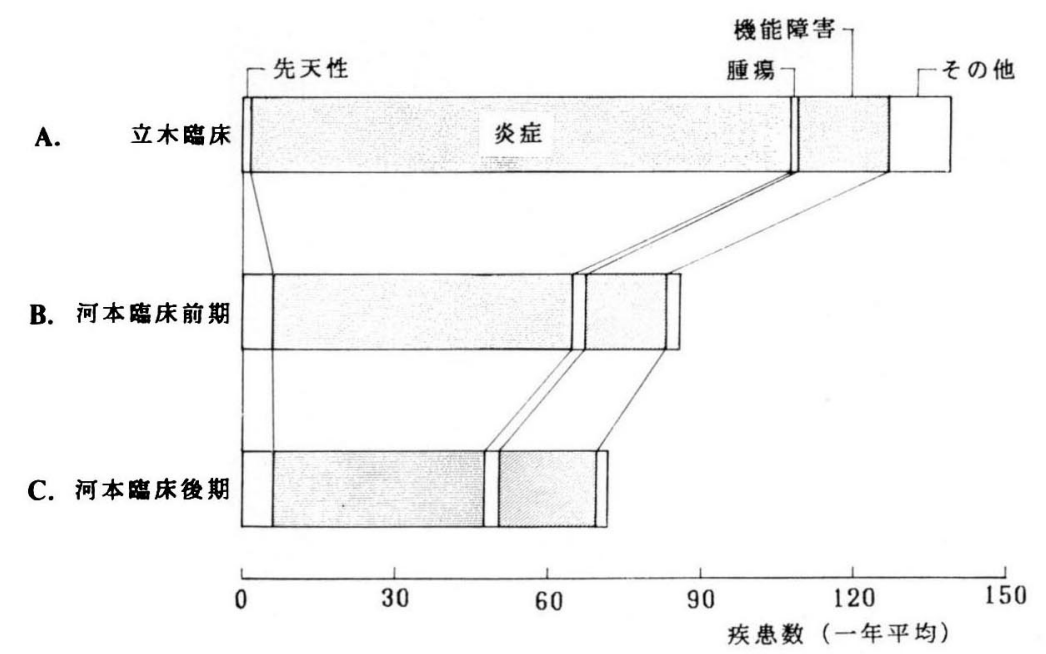

図 4 耳疾患 
表 |

\begin{tabular}{|c|c|c|c|c|c|c|c|c|c|}
\hline 度 & 53 & 54 & 55 & 56 & 57 & 58 & 59 & ${ }_{4}^{60} \sim_{8}$ 月 & 計 \\
\hline \multicolumn{10}{|l|}{ 〔外耳疾患〕 } \\
\hline 先天性 & 5 & 4 & 2 & 3 & 6 & 3 & 5 & 4 & 32 \\
\hline 異 物 & & 1 & & & & & 1 & & 2 \\
\hline 炎 症 & 1 & 2 & 3 & & & 2 & & & 8 \\
\hline 腫 煌 & 2 & 3 & 2 & 1 & 1 & 3 & 1 & & 13 \\
\hline その他 & 2 & & & 1 & & 2 & & & 5 \\
\hline 小 計 & 10 & 10 & 7 & 5 & 7 & 10 & 7 & 4 & 60 \\
\hline \multicolumn{10}{|l|}{ 〔中耳疾患〕 } \\
\hline 先天性 & 3 & 2 & 3 & & 1 & & 2 & 2 & 13 \\
\hline 外 傷 & 1 & 1 & 2 & 2 & 1 & 1 & & & 8 \\
\hline 急性·慢性·滲出性中耳炎 & 34 & 33 & 25 & 20 & 29 & 12 & 14 & 8 & 175 \\
\hline 真珠腫性中耳炎 & 12 & 29 & 12 & 17 & 18 & 19 & 10 & 8 & 125 \\
\hline 顔面神経麻痺 & 7 & 6 & 3 & 2 & 5 & 9 & 7 & 4 & 43 \\
\hline その他 & & 1 & 2 & 1 & 1 & & & & 5 \\
\hline 小 計 & 57 & 72 & 47 & 42 & 55 & 41 & 33 & 22 & 369 \\
\hline \multicolumn{10}{|l|}{ 〔内耳疾患〕 } \\
\hline 感音性難聴 & 16 & 15 & 7 & 9 & 6 & 6 & 8 & 6 & 73 \\
\hline めまい & 2 & 12 & 1 & 3 & 3 & 1 & 2 & 1 & 25 \\
\hline 腫 演 & 2 & 1 & 1 & & 1 & & & & 5 \\
\hline その他 & 1 & & & & & & & & 1 \\
\hline 小 計 & 21 & 28 & 9 & 12 & 10 & 7 & 10 & 7 & 104 \\
\hline \multicolumn{10}{|l|}{ 〔顔面疾患〕 } \\
\hline 外 傷 & 2 & 3 & 4 & 3 & 1 & 1 & 2 & 2 & 18 \\
\hline 炎 症 & 1 & & & & & 1 & & & 2 \\
\hline 腫 演 & 2 & 1 & 1 & 1 & 1 & & & & 6 \\
\hline その他 & & & & & 1 & & 1 & & 2 \\
\hline 小 計 & 5 & 4 & 5 & 4 & 3 & 2 & 3 & 2 & 28 \\
\hline \multicolumn{10}{|l|}{ 〔畺・副鼻腔疾患〕 } \\
\hline 先天性 & 3 & 8 & 1 & 2 & & 3 & 4 & 1 & 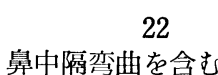 \\
\hline 外 傷 & 8 & 6 & 2 & 7 & 8 & 5 & 9 & 4 & 49 \\
\hline 鼻出血 & 12 & 8 & 16 & 16 & 18 & 11 & 18 & 9 & 108 \\
\hline 炎 症 & 16 & 27 & 16 & 17 & 20 & 18 & 14 & 8 & 136 \\
\hline 鼻 茸 & 10 & 6 & 4 & 7 & 7 & 6 & 4 & 2 & 46 \\
\hline 術後性囊胞 & 27 & 19 & 14 & 27 & 11 & 17 & 8 & 8 & 131 \\
\hline 非術後性囊胞 & 16 & 15 & 10 & 13 & 15 & 13 & 11 & 7 & 100 \\
\hline 腫 瘍 & 17 & 28 & 18 & 18 & 22 & 20 & 20 & 9 & 152 \\
\hline その他 & 3 & 6 & 2 & 1 & 1 & 1 & & 1 & 15 \\
\hline 小 計 & 112 & 123 & 83 & 108 & 102 & 94 & 88 & 49 & 759 \\
\hline \multicolumn{10}{|l|}{ 〔口腔・舌疾患〕 } \\
\hline 先天性 & 1 & & & 2 & 2 & & 1 & & 6 \\
\hline 外 傷 & & 2 & 1 & 3 & & & 2 & & 8 \\
\hline 炎 症 & 4 & 1 & 1 & 5 & 1 & 2 & 3 & 1 & 18 \\
\hline 囊 胞 & 3 & 1 & 1 & & 1 & & & & 6 \\
\hline $\begin{array}{l}\text { 腫 瘍 } \\
\text { その他 }\end{array}$ & 26 & 17 & 16 & 15 & $\begin{array}{r}17 \\
1\end{array}$ & 24 & $\begin{array}{r}19 \\
1\end{array}$ & 6 & $\begin{array}{r}140 \\
2\end{array}$ \\
\hline 小計 & 34 & 21 & 19 & 25 & 22 & 26 & 26 & 7 & 180 \\
\hline
\end{tabular}




\begin{tabular}{|c|c|c|c|c|c|c|c|c|c|}
\hline 年 度 & 53 & 54 & 55 & 56 & 57 & 58 & 59 & $\begin{array}{l}60 \\
4 \sim 8 \text { 月 }\end{array}$ & 計 \\
\hline \multicolumn{10}{|l|}{ 〔唾液腺疾患〕 } \\
\hline 炎 症 & 2 & 3 & 1 & & 1 & 4 & 1 & & 12 \\
\hline 嘸 石 & 1 & 2 & 1 & 2 & 4 & 4 & 1 & & 15 \\
\hline ガマ腫 & & & 2 & & 2 & & & & 4 \\
\hline 腫 瘍 & 7 & 15 & 18 & 7 & 14 & 17 & 10 & 8 & 96 \\
\hline その他 & & & & & & 1 & & & 1 \\
\hline 小 計 & 10 & 20 & 22 & 9 & 21 & 26 & 12 & 8 & 128 \\
\hline \multicolumn{10}{|l|}{ 〔咽頭疾患〕 } \\
\hline 異 物 & 1 & & 1 & & 1 & 4 & 1 & & 8 \\
\hline 炎 症 & 45 & 34 & 26 & 24 & 24 & 34 & 13 & 16 & 216 \\
\hline アデノイド & 14 & 5 & 6 & 10 & 9 & 4 & 1 & 3 & 52 \\
\hline 腫＼cjkstart瘍 & 17 & 21 & 16 & 21 & 16 & 27 & 19 & 9 & 146 \\
\hline & & & & & & \multicolumn{2}{|c|}{ 上咽頭 50 例 } & , 中咽頭31例, & 下咽頭54例 \\
\hline その他 & 1 & 2 & 1 & & 2 & 1 & & & 7 \\
\hline 小計 & 78 & 62 & 50 & 55 & 52 & 70 & 34 & 28 & 429 \\
\hline \multicolumn{10}{|l|}{ [喉頭疾患] } \\
\hline 外 傷 & & & & 2 & & & & & 2 \\
\hline 炎 症 & 18 & 9 & 8 & 5 & 10 & 3 & 2 & 5 & 60 \\
\hline 喉頭ポリープ & 24 & 21 & 25 & 31 & 25 & 23 & 27 & 10 & 186 \\
\hline 垔 胞 & 3 & 1 & & 4 & & 2 & 1 & 1 & 12 \\
\hline 腫 瘍 & 29 & 36 & 29 & 29 & 30 & 28 & 21 & 16 & 218 \\
\hline 反回神経麻痺 & 2 & & & & 1 & & 2 & 2 & 7 \\
\hline その他 & 1 & 1 & 1 & & 3 & & 4 & & 10 \\
\hline 小計 & 77 & 68 & 63 & 71 & 69 & 56 & 57 & 34 & 495 \\
\hline \multicolumn{10}{|l|}{ 〔食道疾患〕 } \\
\hline 異 物 & 21 & 15 & 14 & 8 & 27 & 9 & 19 & 10 & 123 \\
\hline 炎 症 & & 1 & 1 & & 1 & & & & 3 \\
\hline 腫 瘍 & & 1 & & 3 & 1 & & & & 5 \\
\hline その他 & & & & 1 & & & 1 & & 2 \\
\hline 小 計 & 21 & 17 & 15 & 12 & 29 & 9 & 20 & 10 & 133 \\
\hline \multicolumn{10}{|c|}{ 〔気管・気管支祑患〕 } \\
\hline 異 物 & 9 & 13 & 10 & 14 & 14 & 9 & 11 & 6 & 86 \\
\hline カニューレ抜去困難 & & 1 & & 2 & & & & & 3 \\
\hline その他 & 1 & 2 & 1 & 2 & 2 & 4 & 1 & & 13 \\
\hline 小計 & 10 & 16 & 11 & 18 & 16 & 13 & 12 & 6 & 102 \\
\hline \multicolumn{10}{|l|}{ 〔頸部疾患] } \\
\hline 先天性 & 3 & 2 & 6 & 2 & 3 & 9 & 7 & 5 & 37 \\
\hline 炎 症 & 3 & & 6 & 3 & 3 & 7 & 5 & & 27 \\
\hline 腫 瘍 & 7 & 2 & 4 & 1 & 8 & 6 & 8 & 3 & $\begin{array}{c}39 \\
\text { 甲状腺13例 }\end{array}$ \\
\hline その他 & & & 2 & 1 & 2 & 2 & & & 7 \\
\hline 小計 & 13 & 4 & 18 & 7 & 16 & 24 & 20 & 8 & 110 \\
\hline [その他 $]$ & 3 & 2 & 2 & 1 & 2 & 2 & 3 & 2 & 17 \\
\hline [合 計〕 & 451 & 447 & 351 & 369 & 404 & 380 & 325 & 187 & 2914 \\
\hline
\end{tabular}


る.食道疾患も有意に増加している（A から $\mathrm{B}: \mathrm{p}<0.05, \mathrm{~A}$ から $\mathrm{C}: \mathrm{p}<0.01)$. 唾液腺 疾患は $\mathrm{A}$ から $\mathrm{B}(\mathrm{p}<0.001) ， \mathrm{~B}$ から $\mathrm{C}(\mathrm{p}<$ 0.01）と，それぞれ有意に増加している. 頸 部疾患は $\mathrm{A}$ から $\mathrm{B} \cdot \mathrm{C}$ 一有意に増加している $(\mathrm{p}<0.001)$. 気管・気管支疾患はAから $\mathrm{B}$ $(\mathrm{p}<0.001) ， \mathrm{~B}$ から $\mathrm{C}(\mathrm{p}<0.05) 八 ， そ れ$ ぞれ有意に増加している.

全体として見ると, 文字通り耳鼻咽喉疾患が
ほとんどを占めていた $\mathrm{A}$ に比較して， B・C 至って䫓頸部全域へと守備範囲が拡大している と言えよう。ささらに，それぞれの部位について 炎症性疾患, 腫瘍性疾患 etc, 之疾患別飞分類 し比較を試みた． A・B・C それぞれ期間が異 なるため，一年平均を算出して比較を容易にし た. 耳疾患（図4）ではAからB・Cへと炎症 性疾患数の大幅な減少を示し，それが耳疾患総 数の減少となっている. 比率について統計学的

A.

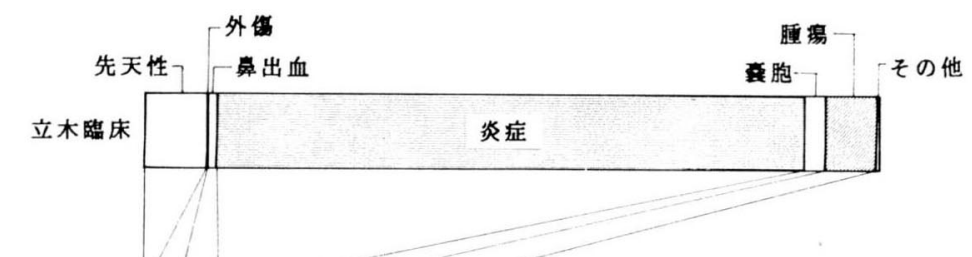

B. 河本躁床前期

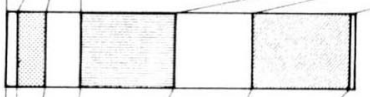

C. 河本畹床後期
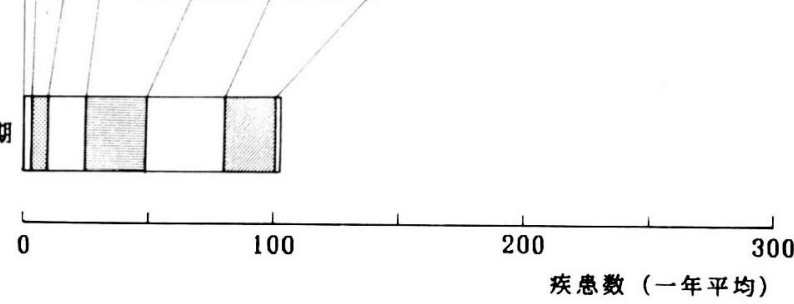

図 5 鼻・副鼻腔疾患

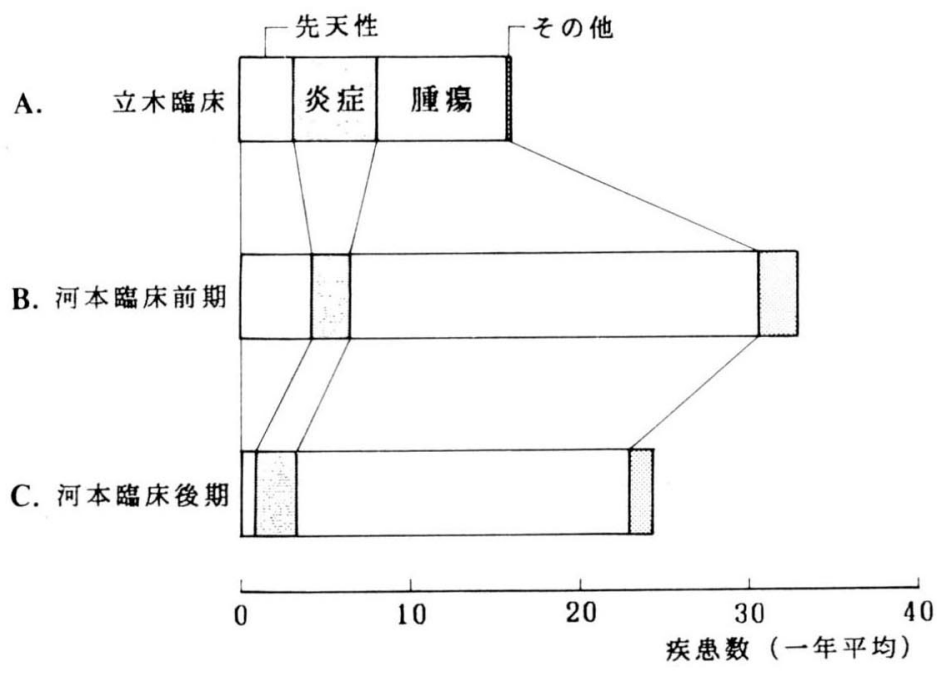

図 6 口腔・舌疾患 
な検定を加えてみると，炎症性疾患の比率は $\mathrm{A}$ と $\mathrm{B} ， \mathrm{~B}$ とには有意差はないが， $\mathrm{A}$ とCでは 有意に減少 $(\mathrm{p}<0.01)$ している. 先天性疾患 は Aから B及び C八有意に増加 $(\mathrm{p}<0.05)$ し ており, 機能障害（感音難聴・めまい・顔面神 経麻痺など）の比率は $\mathrm{A}$ と C の間に有意に増加 $(\mathrm{p}<0.05)$ が見られる.

鼻・副鼻腔疾患 (図 5 ) では, 炎症性疾患 （副鼻腔炎・鼻炎・鼻茸を含む）の著減が明ら
かである．全体に対する比率を見ても，Aと B ・Cの間には有意差がある $(\mathrm{p}<0.001)$. 外傷 ・鼻出血・囊胞性疾患はいずれも，Aから B ・

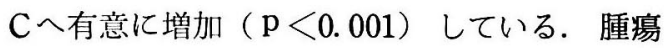
は数から見るとあまり変化していないが, 疾患 総数の減少に伴って比率は有意に增加 $(\mathbf{p}<$ 0.001）している.

口腔・舌疾患（図 6)，唾液腺疾患（図 7 ） では腫瘍性疾患の増加が著明である。特に唾液

A.
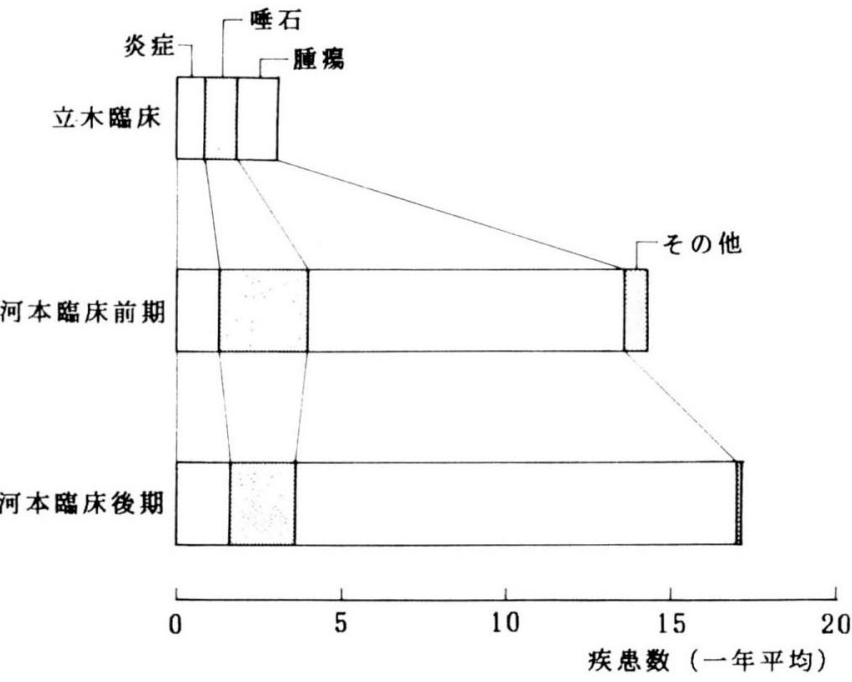

図 7 唾液腺送患

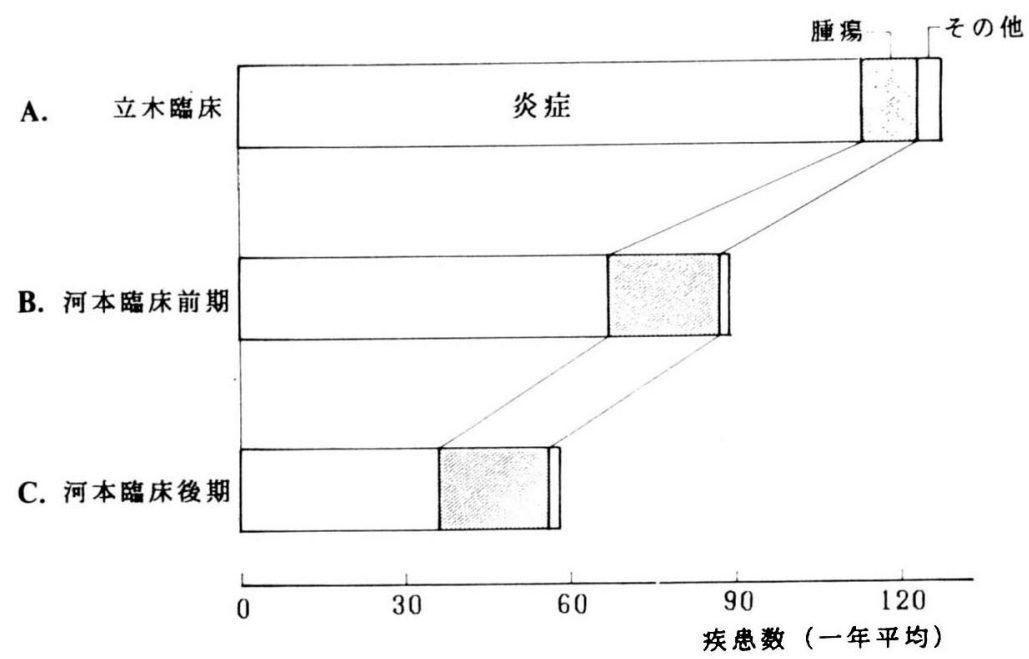

図 8 咽頭疾患 
腺疾患における腫瘍（ガマ腫をむ含む）はAに 対してCは10倍にも増加しており刮目すべきで ある。

咽頭疾患（図 8 ）では炎症性疾患の減少傾向 が明らかである．比率を見てむ有意に低下し ている（A-B間： $\mathrm{p}<0.01 ， \mathrm{~A}-\mathrm{C}$ 間 : $\mathrm{p}<$ 0.001). 腫瘍の増加は数にすると 2 倍程度であ るが, 全体数の減少のため, 比率は有意に上昇 している（A-B間： p <0.01， A-C間 : $p$
$<0.001)$.

矣頭疾患（図 9 ）では, 炎症性疾患（喉頭ポ リープも含めている）がやや減少し，腫瘍は増 加（ $\mathrm{A}-\mathrm{C}$ 間で 2 倍強）している。機能障官と は反回神経麻瘏等である.

企道疾患（図10）では，A・B・Cともに異 物が大部分を占めている。乙こでは炎症性疾患

・腫瘍性疾患と屯に減少を示している.

気管・気管支疾患（図11）でも異物がほとん

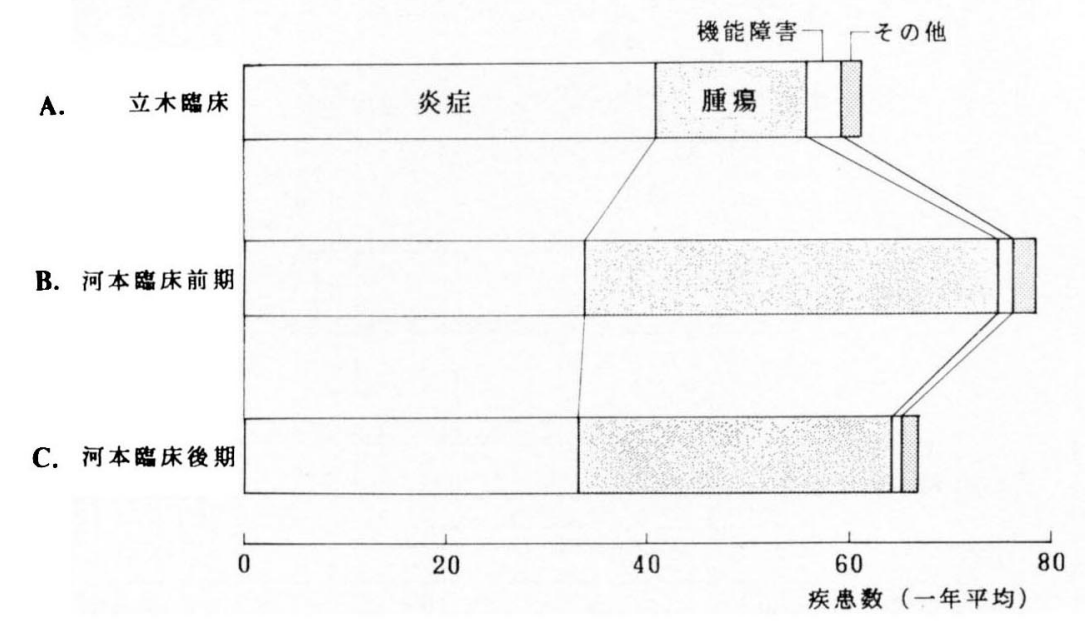

図 9 喉頭疾患

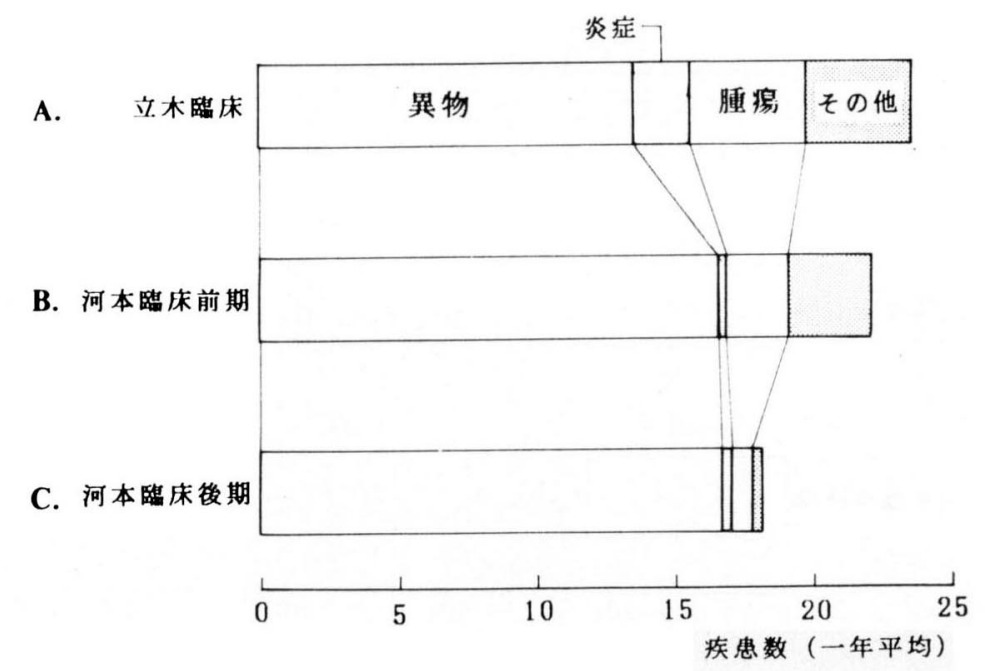

図10食道疾患 
どを占めるようになってきている.

頭頸部疾患（図12）では，Cの集計方法が A

・ B と異なり, 悪性腫瘍の頸部リンパ節転移を 独立した疾患として数えていないという違いは あるが, 疾患数の増加, 特に腫瘍性疾患の増加 が見られる.

全部位についてまとめたのが図13である。一 年平均入院患者数の減少は主として, 長期療菁 を要する頭頸部悪性腫瘍患者の比率の増加によ
ると思われる．抗生物質の発達により感染症の 重症化は少なくなっているため，入院患者の減 少から炎症性疾患の䍜患率の減少を結論すると とはできない，一方，腫痬性疾患の増加は間違 いないであろう，腫瘍性疾患のみならず，外傷 ・異物・副鼻腔囊胞・出血 (鼻出血等) は増加 傾向にあり， $\mathrm{A}-\mathrm{C}$ 間に比率の有意の上昇 $(\mathrm{p}$ $<0.001 ）$ が見られる.

以上, 当教室の入院患者統計の変遷につき解

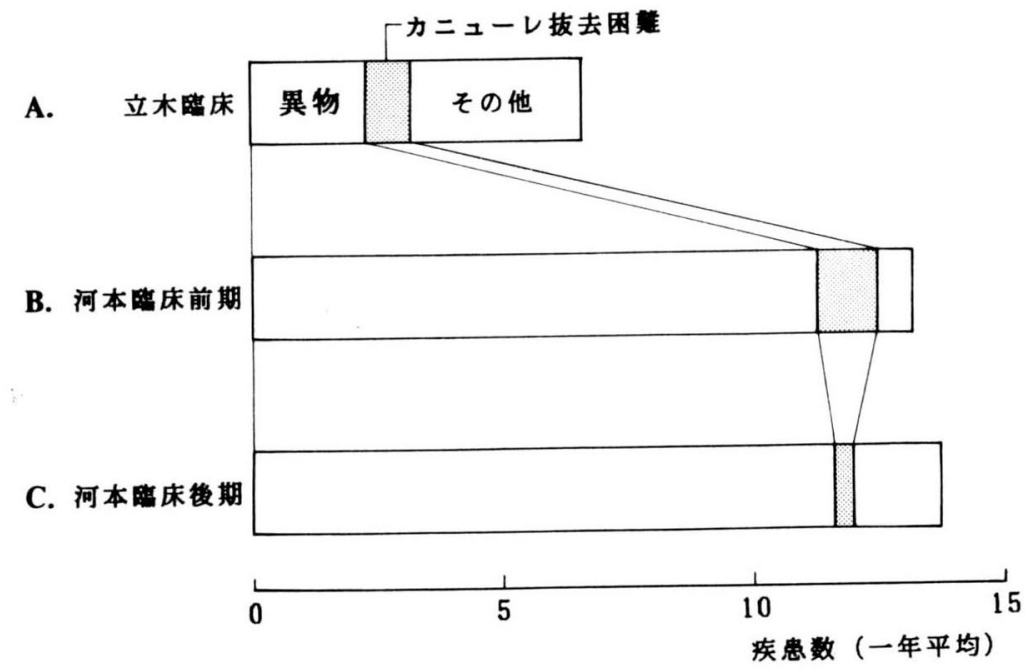

图II 気管・気管支疾患

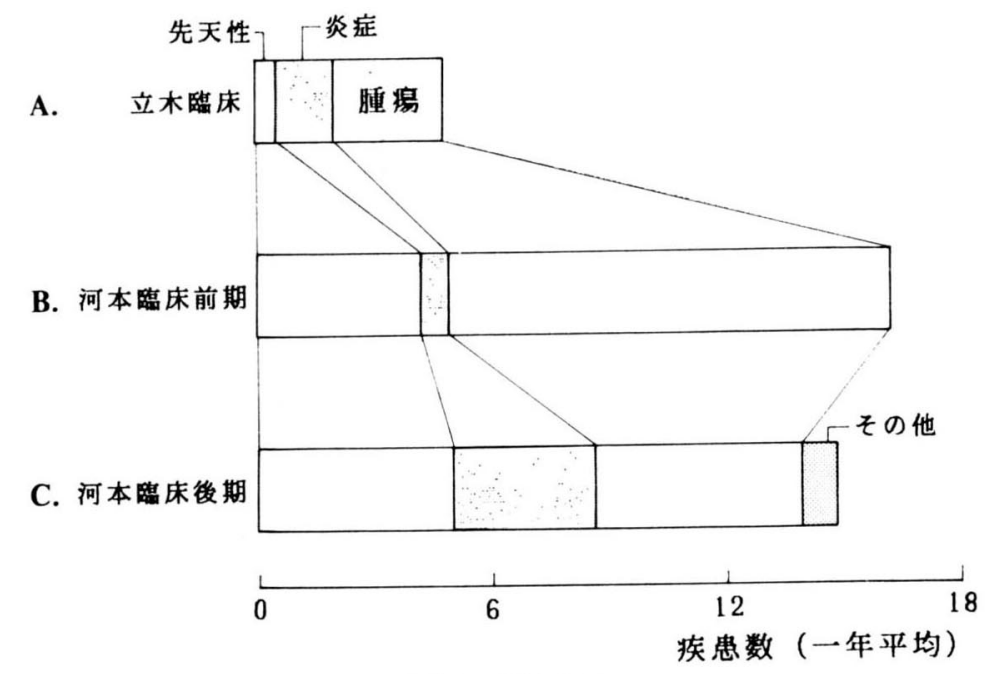

図12 頸部疾患 


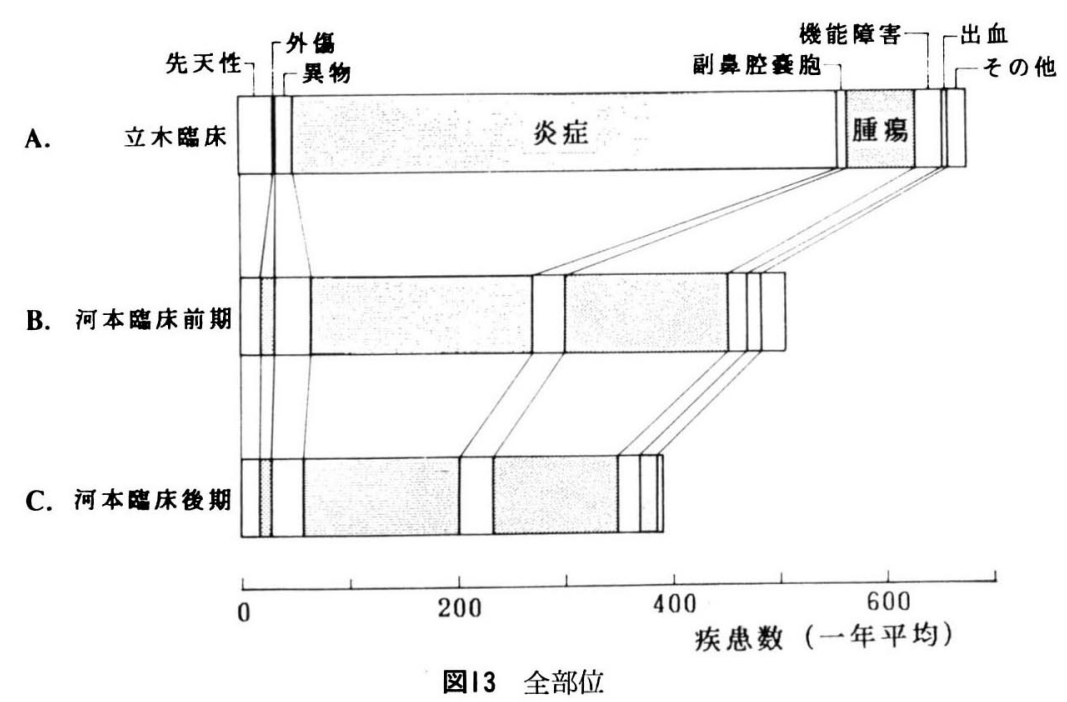

析を試みた。

入院患者統計の推移には, 主として以下の 4 つの要素の影響が考えられる．1. 疾患や治療 法の変遷 (純医学的要素), 2 . 当科の地域医 療に占める役割の変化， 3 . 隣接領域診療科之 の守備範囲の関係，4. 当該期間の教室の研究 テーマである.

したがって, 高次医療機関である大学病院之 いう特殊性をも考虑すると当科の入院患者統計 を耳鼻咽喉科疾患の変遷にまで敷衍することは 勿論不可能である.

しかしながら, 炎症性疾患の減少と, これに 対応する悪性腫瘍患者の比重の増大, 耳鼻咽㗹 科から頭頸部外科への守備範囲の拡大は間違い ない事実といえよう.

\section{まとめ}

河本臨床後期 7 年 5 か月間の疗患集計を行な い, 河本臨床前期（炤和 47 年度 52 年度）及び 立木臨床 (昭和15年度 36年度) の集計との比 較を行なった結果, 以下の結論を得た.

1 ）一年平均の入院患者数は減少している. 長期療養を要する悪性腫瘍患者の増加が原因之
考えられる.

2 ）部位別の割合では喉頭・品・舌・食道 ・唾液腺・気管・気管支の疾患が増加してお り, 立木臨床当時と比べると頭頸部全域に領域 を拡げていると言える.

3 ）疾患別に見ると, 炎症性疾患が減少する 一方, 腫煌性疾患 - 外傷 - 異物 - 副鼻腔囊胞 出血などの増加がみられる. 特に腫瘍性疾患の 増加は顕著である. 先天性疾患, 機能障害の比 率は変化がなかった。

\section{参考文献}

1) 鈴木 孚：患者統計について. 立木 豊教授退官 記念論文集（東北大学医学部耳鼻咽喉科学教室 編). 23〜37頁, 1962.

2 ) 荒川栄一, 高坂知節 : 我教室六年間の耳鼻咽喉, 頭頸部, 気管食道疾患の年度別推移. 耳鼻 25 : 143 145, 1979.

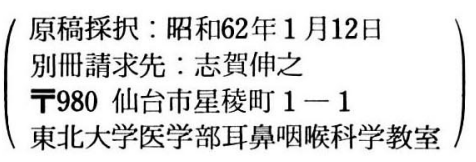

